\title{
HtrA1 as a promising tissue marker in cancer: a meta-analysis
}

\author{
Emma Altobelli ${ }^{1} 2^{*}$, Paolo Matteo Angeletti ${ }^{3}$, Manrico Morroni ${ }^{4}$ and Valerio Filippo Profeta ${ }^{5}$
}

\begin{abstract}
Background: HtrA1 is expressed in a variety of normal human tissues and seems to be involved in numerous physiological processes as well as tumorigenesis. This study reports the results of a meta-analysis that was performed: to compare HtrA1 expression as mRNA and protein, in cancer tissue versus non-cancer tissue and to assess overall survival in relation to low or medium-high HtrA1 tissue expression.

Methods: The PRISMA method was used for study selection. OR and HR with 95\% confidence interval was used as a measure of effect size as appropriate. A random-effects model was applied to account for different sources of variation among studies. Heterogeneity across studies was assessed using Q statistic. Sensitivity analysis was conducted to check the stability of study findings. Egger's regression method was applied to test funnel plot asymmetry.

Results: Sensitivity analysis indicated the stability of meta-analytic findings in each meta-analysis. The study found a significantly different HtrA1 expression in cancer and non-cancer tissue. The meta-analysis of the prognostic studies showed a different survival according to HtrA1 expression.

Conclusions: The present data may provide a contribution to future work directed at exploring the role of HtrA1 in tumor development and progression and at establishing whether it may be used as a promising tissue marker for some tumors.
\end{abstract}

Keywords: HtrA1, Cancer, Meta-analysis

\section{Background}

The members of the widely conserved high-temperature requirement A (HtrA) family of homo-oligomeric serine proteases are involved in a number of mammalian cellular processes that include growth [1], maintenance of mitochondrial homeostasis [2], apoptosis [3], and protein quality control [4]. HtrA1 has been reported to regulate such processes through modulation of growth factor systems, like the system mediated by the extracellular protein transforming growth factor $\beta$ (TGF- $\beta$ ) [5] as demonstrated by the association of its expression with specific tumor behaviors.

Mammalian HtrA1 is connected to tumorigenesis [6, 7]; in particular, it is down-regulated in ovarian [8], thyroid [9], endometrial [10], and breast cancer [11], in hepatocellular carcinoma [12], and colorectal cancer [13] while its up-regulation seems to induce suppression of tumor cell

\footnotetext{
* Correspondence: emma.altobelli@cc.univaq.it

${ }^{1}$ Department of Life, Health and Environmental Sciences, University of L'Aquila, L'Aquila, Italy

${ }^{2}$ Head of Epidemiology and Biostatistics Unit, ASL Teramo, Teramo, Italy

Full list of author information is available at the end of the article
}

proliferation and migration in highly invasive melanoma [6]. Indeed, several lines of evidence indicate that HtrA1 functions as a tumor suppressor in various solid tumors, such as ovarian and lung cancer and mesothelioma $[8,14,15]$. It also participates in regulating cancer cell apoptosis, invasion, and metastasis processes [16]. Distant metastasis, the final stage of solid tumors, is involved in most cancer deaths [16].

By using different experimental techniques, Lorenzi and colleagues [17] have found that HtrA1 protein expression is downregulated in urothelial cancer tissue regardless of tumor grade and stage, and suggested that urinary HtrA1 protein may be used as an early and highly sensitive and specific biomarker for this neoplasm.

Finally, according to recent evidence HtrA1 downregulation induces the acquisition of phenotypes such as increased proliferation, delayed onset of senescence, altered centrosome number and positioning and polyploidy, all hallmarks of tumor cells [18].

In a previous review, our group explored the potential role of HtrA1 as a tumor marker and/or prognostic factor [19]. 
This study reports the results of a meta-analysis that was performed: i) to compare HtrA1 expression as protein and mRNA, in cancer tissue $(\mathrm{C})$ versus non-cancer tissue, i.e. healthy control (HC) tissue and normallooking (NL) tissue; and ii) to assess overall survival in relation to low or medium-high HtrA1 tissue expression in different cancers.

\section{Methods}

Literature search. Relevant studies were identified as of June 2017 using the following databases: PubMed, Embase, Web of Science, Cochrane Library, Scopus, and clinical trial registers (clinicaltrial.gov, clinicaltrialsregister.eu). A manual search was also performed. There were no limitations as to the year of publication. Only studies in English were considered. The reference lists of all studies were screened by two independent reviewers (PMA and MM); any disagreements were resolved by a methodologist (EA). The following keys words were used: HtrA1 OR PRSS11 protein, human OR L56 protein, human OR protease, serine, 11 (IGF binding) protein, human OR high-temperature requirement factor A1, human OR HtrA serine peptidase 1, human AND Neoplasm OR Tumors OR Tumor OR Neoplasia OR Cancer OR Cancers. Only studies assessing HtrA1 (mRNA or protein) as a diagnostic or prognostic tumor marker were considered. Studies were selected using the PRISMA statement (Additional file 1: Figure S1) [20]. The excluded studies and the PRISMA check list are reported in Additional file 2: Table S1 and Additional file 3: Table S2. The general characteristics of each study (tumor site, sample size, patient population) are reported in Table 1. The Newcastle-Ottawa was used for casecontrol studies was used (Additional file 4: Table S3).

\section{Statistical analysis}

For the number of studies to be included in the metaanalysis, we made reference to Davey J et al. [21].

Odds Ratios (ORs) [22, 23], with 95\% confidence interval (CI) and $p$ value, were used as a measure of effect size when comparing $\mathrm{C}$ to $\mathrm{HC}$ tissue and $\mathrm{C}$ to NL tissue. The scores of immunostaining of HtrA1 expression reported in each study, were ranked as follow: samples ranked as 0,1 or negative, were classified as "low expression" and those ranked as 2, 3 or 4, were classified as "medium-high expression".

Effect sizes were pooled across studies to obtain an overall effect size. A random-effects model was applied as a conservative approach to account for different sources of variation among studies. Heterogeneity across studies was assessed using Q statistic, I2, Tau, and Tau2. A significant $Q$ value indicated the absence of homogeneity of results among studies.
In addition, to complete the explanation of heterogeneity across study results, moderator analyses were conducted if there were at least 5 studies. The moderators evaluated by meta-regressions were sample size magnitude, \% of female, mean age of both genders as appropriated, and year of publication.

Sensitivity analysis was conducted to check the stability of study findings and estimate how the overall effect size would be modified by removal of one study.

Publication bias analyses were performed when there were at least 4 studies, to control for the fact that published studies may have a larger mean effect size than unpublished studies [24]. The funnel plot, namely a scatter plot of the effect sizes estimated from individual studies against a measure of their precision (i.e. their standard error), was examined; in absence of bias, its shape should be a symmetric inverted funnel. Egger's regression method [25] was applied to test funnel plot asymmetry. When the results of this analysis are non-significant, there is no publication bias. Finally, the trim and fill procedure was used to evaluate the effect of potential data censoring on meta-analysis results [26]. In this approach, the absence of publication bias is indicated by zero trimmed studies, or if trimmed studies are present, by trivial differences between observed and estimated effect sizes [27].

Prognostic studies were analyzed using the hazard ratio (HR) and its $95 \% \mathrm{CI}$ as a measure of effect size. To assess the effect of HtrA1 expression on overall survival, patients were dichotomized into two classes: mediumhigh and low HtrA1 expression. When the HR and 95\% CI were not reported in the papers, they were estimated from Kaplan-Meier curves according to Parmar et al. [28], Tierney et al. [29], and Williamson et al. [30]. Statistical analysis was performed using Prometa 3.

\section{Results}

Search of the electronic databases according to the above-listed criteria found 59 papers, whereas the manual search found none. There were no duplicates (Additional file 1: Figure S1). In the first phase, 40 papers were excluded because they did not match the inclusion criteria. In the second phase, 19 full papers were examined and 4 more were excluded because they did not match the outcomes of interest [14, 31-33]. Eventually, 15 papers assessing HtrA1 expression at 10 tumours sites (stomach, liver, bladder, breast, esophagus, thyroid, endometrium, pleura, ovary, colorectum cancer) were included in the meta-analysis [9-13, 15, 17, 34-41].

In each meta-analysis, sensitivity analyses indicated stability of meta-analytic findings. 


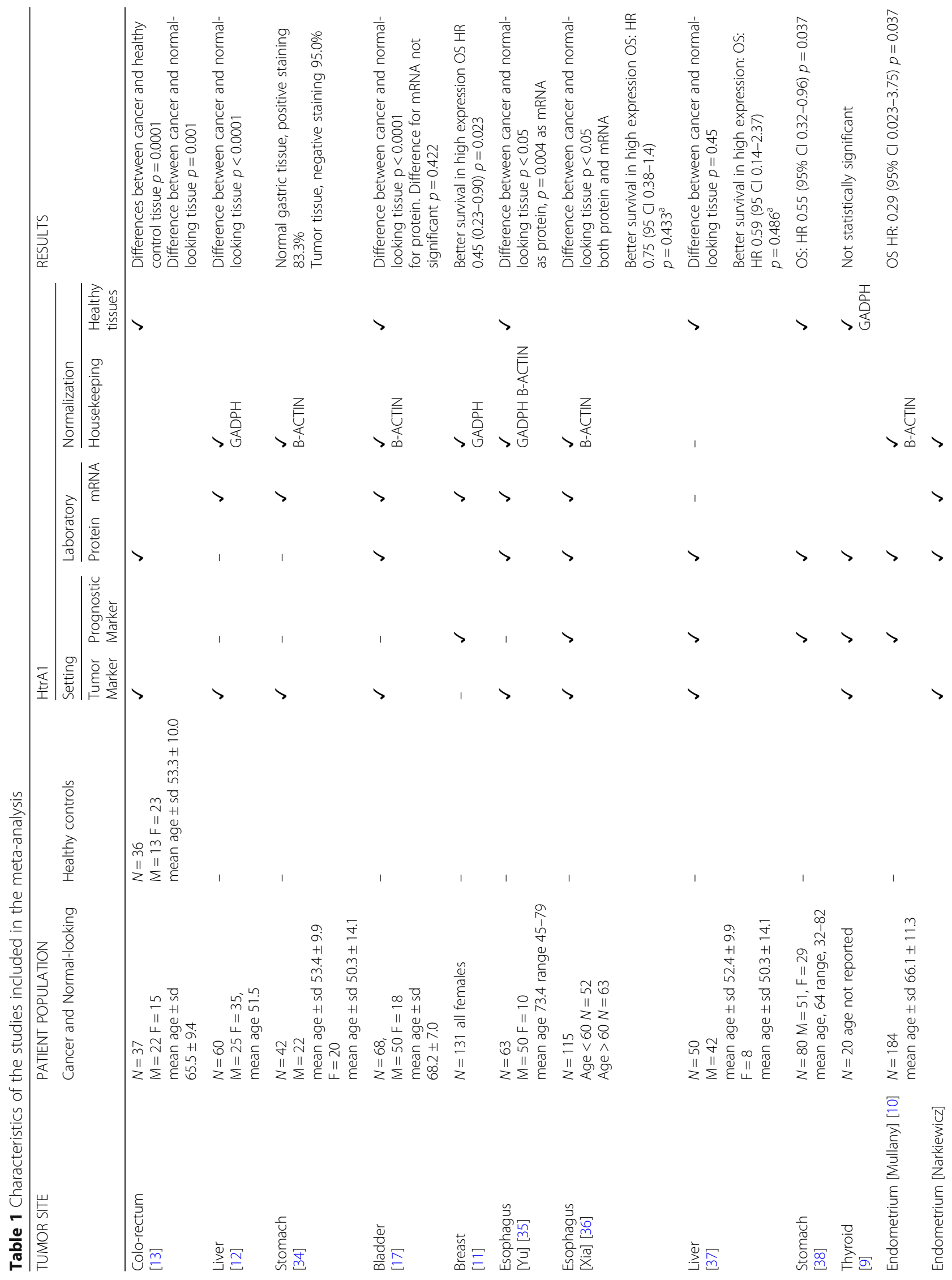




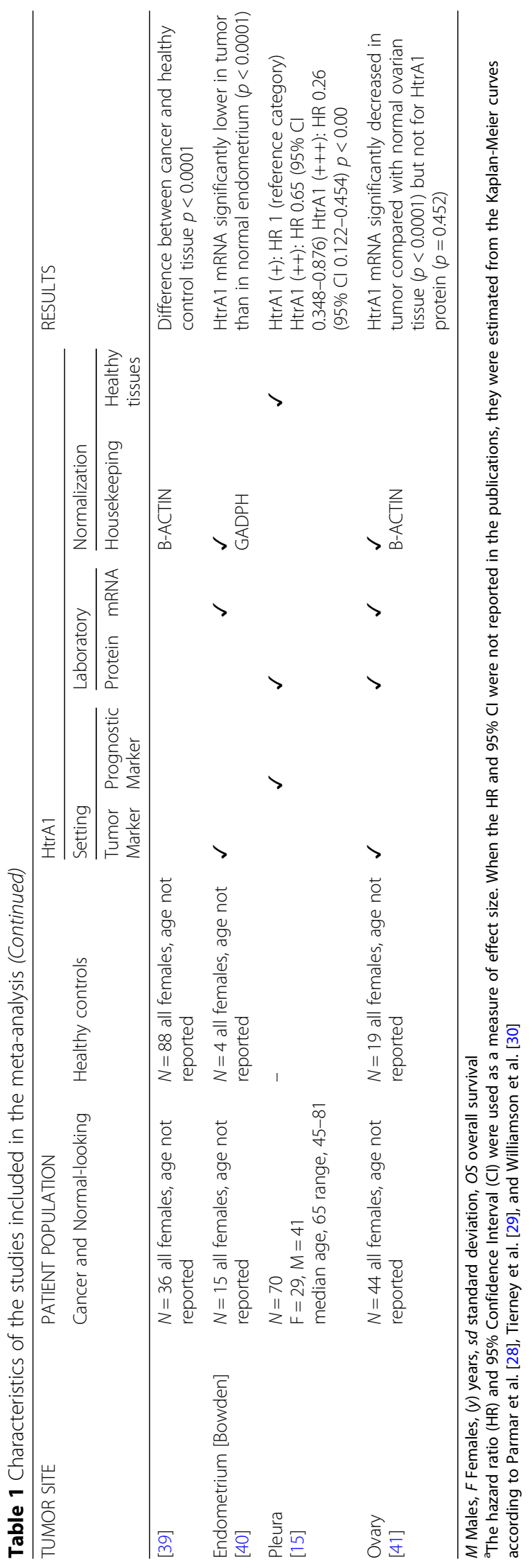




\section{C versus $\mathrm{HC}$ tissue: Expression of HtrA1 in protein and mRNA}

There were 3 studies of HtrA1 expression as protein $[13,39,41]$ and 3 of HtrA1 expression as mRNA [39-41]. As regards HtrA1 expression as protein the overall effect size in $\mathrm{C}$ vs $\mathrm{HC}$ was $\mathrm{OR}=2.91$ (1.80-4.70), $p<$ $0.0001 ; \mathrm{Q}=1.68, \mathrm{I}^{2}=0.00, p=0.432$ (Fig. 1, Table 2). As regards HtrA1 expression as mRNA overall effect size in $\mathrm{C}$ vs $\mathrm{HC}$ was $\mathrm{OR}=3.93$ (2.17-7.15), $\mathrm{p}<0.0001 ; \mathrm{Q}=2.12$, $\mathrm{I} 2=5.81, P=0.346$ (Fig. 1 , Table 2).

\section{C versus NL tissue: Expression of HtrA1 protein}

As regards $C$ vs NL tissue, there were 6 studies $[9,12$, $13,17,35,36]$. The overall effect size was $\mathrm{OR}=2.93$ (2.21-3.90), $\mathrm{p}<0.0001$, with $\mathrm{Q}=4.42, \mathrm{I}^{2}=0.00, p=0.491$ (Table 2, Fig. 2a).

Publication bias analysis did not highlight differences between observed and estimated values ( 0 trimmed studies), and Egger's linear test was not statistically significant: $p=0.334$ (Table 2, Fig. 2b). Meta-regressions for sample size magnitude, $\%$ of females, mean age of both gender, and year of publication did not show statistically significant differences: beta $=0.01, p=0.177$; beta $=0.02$, $p=0.083$, beta $=0.00, p=0.919$; beta $=0.08, p=0.422$ (Additional file 5: Figure S2A, B, C, D).

\section{C versus NL tissue: Expression of HtrA1 mRNA}

As regards $C$ vs NL tissue, there were 5 studies $[12,17$, 34-36]. The overall effect size was $\mathrm{OR}=2.80(1.81-$ 4.32), $p<0.0001, \mathrm{Q}=9.01, p=0.061, \mathrm{I}^{2}=55.59$, without statistically significant heterogeneity (Table 2, Fig. 2a).

Although publication bias analysis trimmed 1 study the result of Egger's linear test, $p=0.798$, was not statistically significant (Fig. 2c). Meta-regressions for sample size magnitude, \% of females, and year of publication did not disclose statistically significant differences: beta $=0.00$, $p=0.816$; beta $=0.02, \quad p=0.218 ; \quad$ beta $=0.09, \quad p=0.633$; (Additional file 6: Figure S3A, B, C). Mean age was not evaluated because too few studies reported data for both genders.

\section{HtrA1 expression and survival analysis}

The second aim of the meta-analysis was to assess overall survival in relation to low and medium-high HtrA1 expression in cancers. The literature search retrieved 7 studies: 2 investigating HtrA1 as mRNA $[11,36]$ and 5 assessing HtrA1 as protein $[10,15,35,36,38]$. As regards mRNA, the overall effect size was $\mathrm{HR}=0.57$ (0.31-1.06), $p=0.076$, without statistical heterogeneity, $\mathrm{Q}=1.21, p=0.272, \mathrm{I}^{2}=17.03$ (Table 2, Fig. 3a). As regards HtrA1 measured as protein, the overall effect size was $\mathrm{HR}=0.51(0.37-0.70), p<0.0005$, without significant heterogeneity, $\mathrm{Q}=2.29, p=0.682, \mathrm{I}^{2}=0.00$ (Table 2, Fig. 3a).

Publication bias analysis and meta-regression were performed only for the studies assessing HtrA1 as protein. The funnel plot did not show differences between observed and estimated values $(0$ trimmed studies), and Egger's linear test was not statistically significant, $p=0.897$ (Table 2, Fig. 3b). Meta-regressions for sample size magnitude, \% of females and year of publication did not show statistical differences: beta $=0.00$, $p=0.806$; beta $=-0.00, p=0.741$; beta $=0.03, p=0.598$ (Additional file 7: Figure S4A, B, C, D).

\section{Discussion}

In recent years, mounting biological knowledge of disease processes and advances in molecular technologies have increased the interest in biomarkers. In fact, biomarkers are used for patient assessment in multiple clinical settings, both to distinguish an individual with disease from one without disease and to discriminate one disease from another, i.e. for differential diagnosis. Ad hoc immune-histochemical markers can also be used to try and identify the tissue where a tumor has had its origin, to assess the risk of relapse, as well as to evaluate prognosis or response to therapy.

In the present study, a meta-analysis was conducted to assess the potential role of HtrA1 as a tumor marker and/or prognostic factor in a number of tumors. Most current studies focus on the role of HtrA1 in tumor development and progression through analysis of its expression as mRNA [11, 12, 17, 34-36, 39-41] or protein $[9,10,13,15,17,35-38]$, probably because proteins

\begin{tabular}{|c|c|c|c|c|c|c|c|c|c|c|c|}
\hline & ES & $95 \% \mathrm{Cl}$ & w & Sig. & $\mathbf{N}$ & N1 & N2 & & & & \\
\hline Altobelli et al. 2016 - Colorectum & 4.30 & $1.81,10.20$ & $30.87 \%$ & 0.001 & 73 & 37 & 36 & $=$ & 1 & & \\
\hline Narkiewicz et al. 2008 - Ovary & 1.81 & $0.68,4.83$ & $23.99 \%$ & 0.236 & 63 & 19 & 44 & & & & \\
\hline Narkiewicz et al. 2009 - Endometrium & 2.87 & $1.40,5.86$ & $45.14 \%$ & 0.004 & 124 & 36 & 88 & & - & & \\
\hline Protein & 2.91 & $1.80,4.70$ & $100.00 \%$ & 0.000 & 260 & 92 & 168 & & & & \\
\hline Bowden et al. 2006 - Endometrium & 11.21 & $1.32,95.59$ & $7.63 \%$ & 0.027 & 19 & 15 & 4 & & & & \\
\hline Narkiewicz et al. 2008 - Ovary & 5.59 & $2.01,15.53$ & $31.83 \%$ & 0.001 & 63 & 19 & 44 & & $=$ & & \\
\hline Narkiewicz et al. 2009 - Endometrium & 2.87 & $1.40,5.86$ & $60.53 \%$ & 0.004 & 124 & 36 & 88 & & - & & \\
\hline \multirow[t]{2}{*}{ mRNA } & 3.93 & $2.17,7.15$ & $100.00 \%$ & 0.000 & 206 & 70 & 136 & & & & \\
\hline & & & & & & & 0.5 & 1 & 10 & 50 & 100 \\
\hline
\end{tabular}


Table 2 Results of the Meta-analysis

\begin{tabular}{|c|c|c|c|c|c|c|c|c|c|c|c|c|}
\hline & \multicolumn{2}{|c|}{ POOLED ANALYSIS } & \multicolumn{5}{|c|}{ HETEROGENEITY } & \multicolumn{4}{|c|}{ PUBLICATION BIAS } & \\
\hline & \multirow[t]{2}{*}{$E S(C l)$} & \multirow[t]{2}{*}{$P$-value } & \multirow[t]{2}{*}{$Q$} & \multirow[t]{2}{*}{$P^{2}$} & \multirow[t]{2}{*}{ P-value } & \multirow[t]{2}{*}{$T^{2}$} & \multirow[t]{2}{*}{$T$} & \multicolumn{2}{|l|}{ Egger's } & \multicolumn{2}{|c|}{ Begg and Mazdumdar's } & \\
\hline & & & & & & & & $T$ & $P$-value & Z & P-value & \\
\hline \multicolumn{13}{|c|}{ Cancer vs Healthy Controls } \\
\hline $\begin{array}{l}\quad \text { Protein } \\
(k=3) \\
{[13,41,39]}\end{array}$ & $2.91(1.80 ; 4.70)$ & $<0.0001$ & 1.68 & 0.00 & 0.432 & 0.00 & 0.00 & - & - & - & - & Fig. 1 \\
\hline $\begin{array}{l}\text { mRNA } \\
(k=3) \\
{[39-41]}\end{array}$ & $3.93(2.17 ; 7.15)$ & $<0.0001$ & 2.12 & 5.81 & 0.346 & 0.02 & 0.14 & - & - & - & - & Fig. 1 \\
\hline \multicolumn{13}{|c|}{ Cancer vs Normal-Looking Tissue } \\
\hline $\begin{array}{l}\quad \text { Protein } \\
(k=6) \\
{[9,12,13,17,35,36]}\end{array}$ & $2.93(2.21 ; 3.90)$ & $<0.0001$ & 4.42 & 0.00 & 0.491 & 0.00 & 0.00 & -1.10 & 0.334 & -1.32 & 0.188 & Fig. 2a, b \\
\hline $\begin{array}{l}\quad \text { mRNA } \\
(k=5) \\
{[12,17,34-36]}\end{array}$ & 2. $80(1.81 ; 4.32)$ & $<0.0001$ & 9.01 & 55.59 & 0.061 & 0.14 & 0.37 & 0.28 & 0.798 & 0.00 & 1.000 & Fig. 2a, c \\
\hline \multicolumn{13}{|l|}{ SURVIVAL } \\
\hline $\begin{array}{l}\text { Protein } \\
(k=5)[10,15,35,36,38]\end{array}$ & $0.51(0.37 ; 0.70)$ & 0.005 & 2.29 & 0.00 & 0.682 & 0.00 & 0.00 & 0.14 & 0.897 & 0.49 & 0.624 & Fig. 3a, b \\
\hline $\begin{array}{c}\text { mRNA } \\
(k=2)[11,36]\end{array}$ & $0.57(0.31 ; 1.06)$ & 0.076 & 1.21 & 17.03 & 0.272 & 0.04 & 0.19 & - & - & - & - & Fig. $3 a$ \\
\hline
\end{tabular}

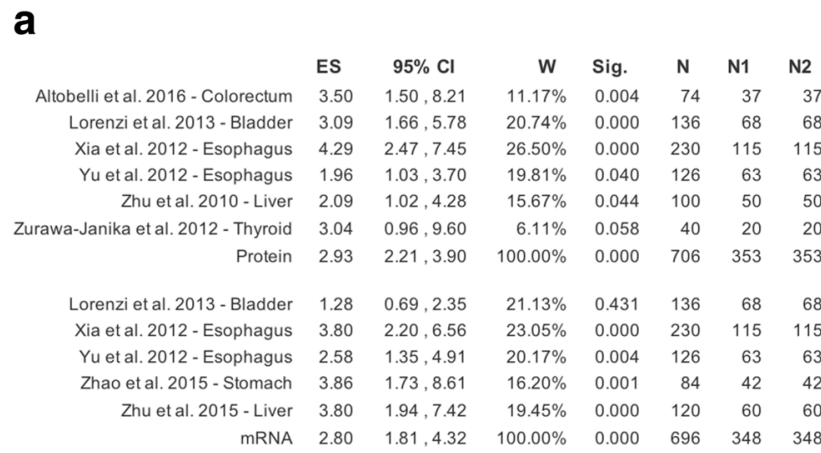

b

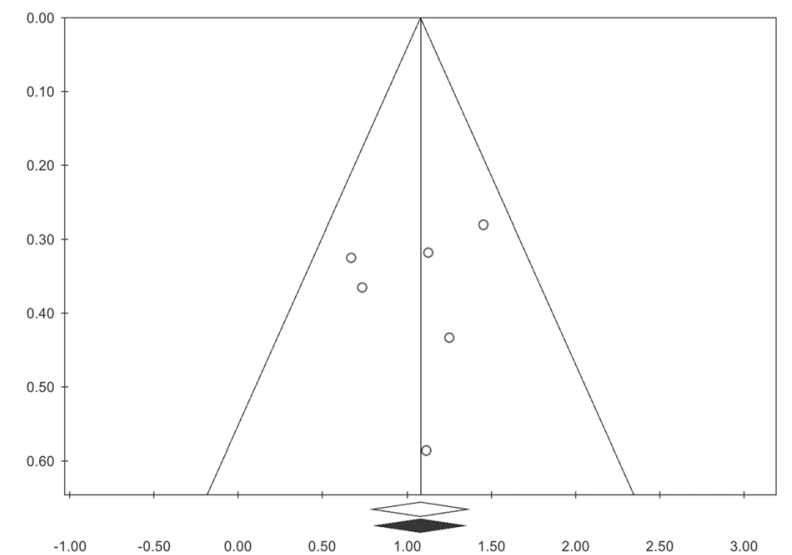

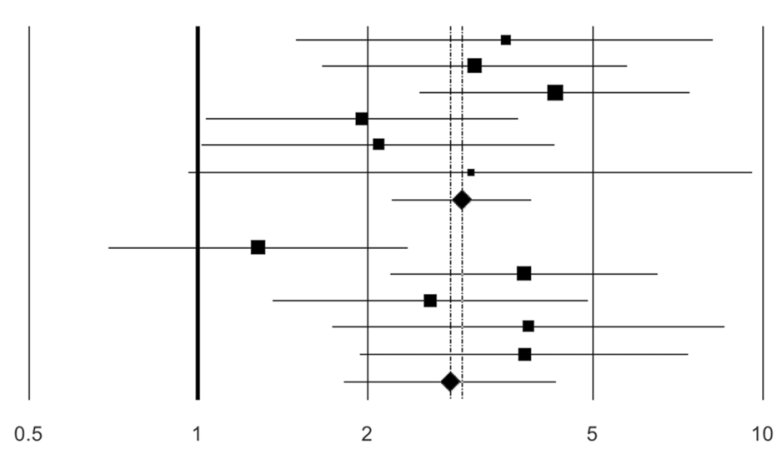

C

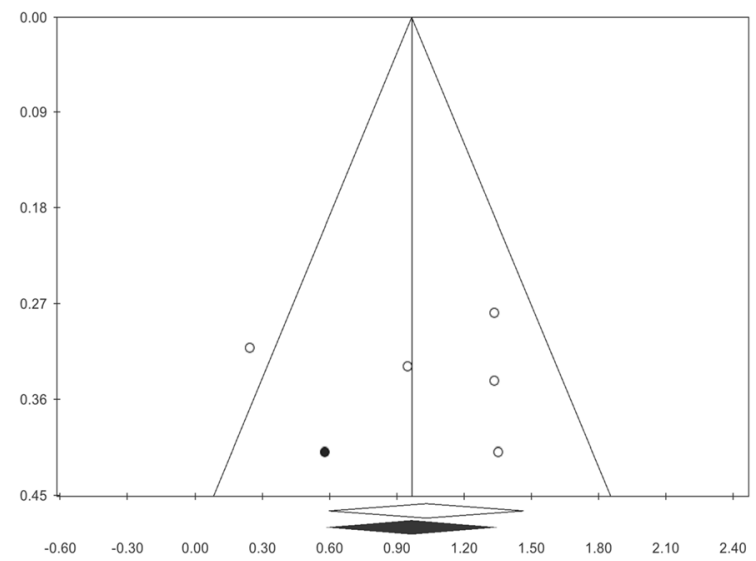

Fig. 2 a Forest plot. HtrA1 protein and mRNA in Cancer Tissue versus Normal-Looking Tissue b Funnel plot. HtrA1 protein in Cancer Tissue versus Normal-Looking Tissue. c Funnel plot. HtrA1 mRNA in Cancer Tissue versus Normal-Looking Tissue 


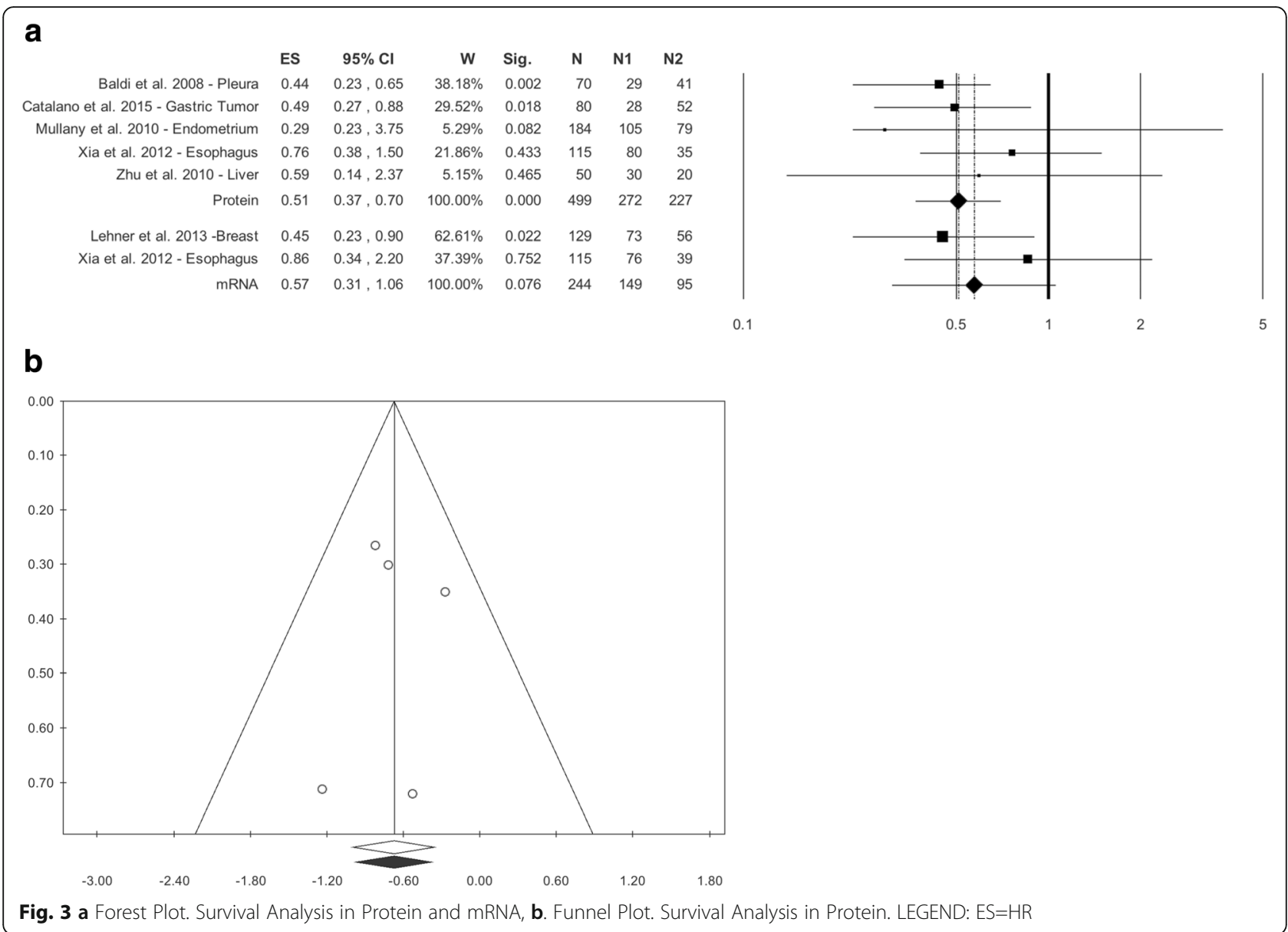

are more varied than DNA or RNA and therefore carry more information than nucleic acids. Indeed, alternative splicing and more than 100 unique post-translational modifications result in tens (and possibly hundreds) of protein species from each gene. Moreover, a number of physiological changes are mediated post-transcriptionally and are not revealed at the nucleic acid level. Proteins are also more dynamic and reflective of cellular physiology. For instance, the occurrence of a single double-strand DNA break in a cell is rapidly amplified into a protein phosphorylation cascade. Thus, protein-based markers provide a fine, specific, and accurate representation of the condition being investigated.

Based on these considerations, in this work the studies assessing HtrA1 expression as mRNA and protein were evaluated separately. An important finding of the study was that, in the absence of significant statistical heterogeneity, there was a statistically significant difference between the tumor samples analyzed and $\mathrm{HC}$ and $\mathrm{NL}$ tissue specimens; this applied both to HtrA1 measured as mRNA and as protein (Table 2, Figs. 1 and 2a,). The results regarding the non-heterogeneity of studies were supported by the analysis of the moderators used, i.e. sample size magnitude, \% of females, mean age for both genders, and year of publication, which did not exhibit statistically significant differences (Additional file 5: Figure S2A, D). Publication bias was highlighted neither by the funnel plot nor by Egger's or Begg's test. A consistent finding of this work, that was described in all the studies that tested this aspect [9-13,15, 17, 34-41], was that HtrA1 levels are higher in HC or NL tissue than in diseased tissue from patients with a variety of tumors.

The meta-analysis of the prognostic studies showed, in the absence of significant heterogeneity among the studies examined, a different survival according to HtrA1 expression. These findings are in line with the literature, since in some studies HtrA1 has been found to modulated cisplatin- and paclitaxel-induced cytotoxicity and low HtrA1 levels have been seen to correlate with a poor response to drug treatment, whereas higher levels correlated with a greater response [38, 42].

Baldi et al. [15] have demonstrated a relationship between HtrA1 expression level and survival in patients with malignant mesothelioma, suggesting that HtrA1 expression can be used as a prognostic parameter for this tumor type. Analysis of HtrA1 levels in relation to 
overall survival and disease free survival in breast cancer [11] indicated that patients with higher HtrA1 levels had a better prognosis.

Analysis of the moderators assessed in the works selected found no statistically significant differences and there was no publication bias (Additional file 7: Figure S4).

However, some weaknesses in the data suggest that the results of the present meta-analysis should be taken with caution. First of all, most of the studies are descriptive, preventing a causal inference between reduced HtrA1 levels and cancer. Secondly, the small number of works on the same tumor prevents an analysis by tumor in relation to individual organs. Thirdly, since parameters such as histological type and tumor grade and stage have not been addressed in all the studies, it is impossible to establish how HtrA1 expression varies in relation to these factors. Finally, the different HtrA1 expression, found in papers assessing the same cancer type, could correlate to histological grading, metastasis, and degree of cell differentiation, but were not related to patients' age or gender, as demonstrated in hepatocellular carcinoma [12], esophageal carcinoma [35, 36] and endometrial cancer $[10,40,41]$. This means that the reduced HtrA1 expression may be closely associated to tumor development. The lack of difference in HtrA1 expression reported by Catalano et al. (2011 [38]) may be due to heterogeneous baseline characteristics of their patients, like constitutional genetic factors and other variables, which as the authors themselves stated were not investigated.

\section{Conclusions}

The present data may provide a contribution to future research work directed at exploring the role of HtrA1 in tumor development and progression and at establishing whether it may become a promising tissue marker for some tumors. Finally, the present work suggests that clinical investigations sharing a similar approach, especially in terms of study design, should be carried out to improve comparability across studies.

\section{Additional files}

Additional file 1: Figure S1. Flow-chart of research strategy. (PDF 252 kb)

Additional file 2: Table S1. Excluded papers. (PDF $288 \mathrm{~kb}$ )

Additional file 3: Table S2. PRISMA Check-list. (PDF $267 \mathrm{~kb}$ )

Additional file 4: Table S3. Newcastle-Ottawa evaluation for casecontrol studies. (PDF $82 \mathrm{~kb}$ )

Additional file 5: Figure S2. Normal-Looking Tissue. Meta-regression of HtrA1 protein: A. Sample size, B. \% Female, C. Mean age of entire sample, D. Publication year. (PDF $218 \mathrm{~kb}$ )

Additional file 6: Figure S3. Normal-Looking Tissue. Meta-regression of HtrA1 mRNA: A. Sample size, B. \% Female, C. Mean age of entire sample, D. Publication year. (PDF $1270 \mathrm{~kb}$ )
Additional file 7: Figure S4. Survival studies. Meta-regression of HtrA1 protein: A. Sample size, B. \% Female, C. Mean age of entire sample, D. Publication year (PDF $149 \mathrm{~kb}$ )

\section{Abbreviations}

C: cancer tissue; HC: healthy control; HR: hazard ratio; OR: odds ratio;

$\mathrm{NL}$ : normal-looking

Acknowledgements

Not applicable

Funding

No specific funding

\section{Availability of data and materials}

All primary studies surveyed are published. To the best of our knowledge, no unpublished studies were available.

\section{Authors' contributions}

AE designed the study, analysed data and literature review, drafting and critical revision and editing; APM participated to literature search, participated in analysing the data and in writing the paper; MM participated to literature search and participated in writing the paper; PFV participated in literature search and critical revision of manuscript. All authors' have read and approved the final version of the manuscript.

Ethics approval and consent to participate

Not applicable.

\section{Consent for publication}

Not applicable.

Competing interests

The authors declare that they have no competing interests.

\section{Publisher's Note}

Springer Nature remains neutral with regard to jurisdictional claims in published maps and institutional affiliations.

\section{Author details}

${ }^{1}$ Department of Life, Health and Environmental Sciences, University of L'Aquila, L'Aquila, Italy. ${ }^{2}$ Head of Epidemiology and Biostatistics Unit, ASL Teramo, Teramo, Italy. ${ }^{3}$ Department of Life, Health and Environmental Sciences, University of L'Aquila, L'Aquila, Italy. ${ }^{4}$ Department of Experimental and Clinical Medicine, Section of Neuroscience and Cell Biology, School of Medicine, Università Politecnica delle Marche, Ancona, Italy. ${ }^{5}$ Department of Community Health, Teramo, Italy.

Received: 29 June 2017 Accepted: 23 January 2018

Published online: 06 February 2018

\section{References}

1. Chien J, Campioni M, Shridhar V, Baldi A. HtrA serine proteases as potential therapeutic targets in cancer. Curr Cancer Drug Targets. 2009;9(4):45168.

2. Gray CW, Ward RV, Karran E, Turconi S, Rowles A, Viglienghi D, et al. Characterization of human HtrA2, a novel serine protease involved in the mammalian cellular stress response. Eur J Biochem. 2000;267(18):5699-710.

3. Zurawa-Janicka D, Skorko-Glonek J, Lipinska B. HtrA proteins as targets in therapy of cancer and other diseases. Expert OpinTher Targets. 2010;14(7):665-79.

4. Clausen T, Southan C, Ehrmann M. The HtrA family of proteases: implications for protein composition and cell fate. Mol Cell. 2002;10(3):443-55.

5. Oka C, Tsujimoto R, Kajikawa M, Koshiba-Takeuchi K, Ina J, et al. HtrA1 serine protease inhibits signaling mediated by Tgfbeta family proteins. Development. 2004;131(5):1041-53.

6. Baldi A, De Luca A, Morini M, Battista T, Felsani A, Baldi F, et al. The HtrA1 serine protease is down-regulated during human melanoma progression and represses growth of metastatic melanoma cells. Oncogene. 2002;21(43):6684-8. 
7. Chien J, Ota T, Aletti G, Shridhar R, Boccellino M, Quagliuolo L, et al. Serine protease HtrA1 associates with microtubules and inhibits cell migration. Mol Cell Biol. 2009;29(15):4177-87.

8. Chien J, Staub J, Hu SI, Erickson-Johnson MR, Couch FJ, Smith DI, et al. A candidate tumor suppressor HtrA1 is downregulated in ovarian cancer. Oncogene. 2004;23(8):1636-44.

9. Zurawa-Janicka D, Kobiela J, Galczynska N, Stefaniak T, Lipinska B, Lachinski $A$, et al. Changes in expression of human serine protease HtrA1, HtrA2 and HtrA3 genes in benign and malignant thyroid tumors. Oncol Rep. 2012;28(5):1838-44.

10. Mullany SA, Moslemi-Kebria M, Rattan R, Khurana A, Clayton A, Ota T, et al. Expression and functional significance of HtrA1 loss in endometrial cancer. Clin Cancer Res. 2011:17(3):427-36.

11. Lehner A, Magdolen V, Schuster T, Kotzsch M, Kiechle M, Meindl A, et al. Downregulation of serine protease HTRA1 is associated with poor survival in breast cancer. PLoS One. 2013;8(4):e60359.

12. Zhu F, Duan YF, Bao WY, Liu WS, Yang Y, Cai HH. HtrA1 regulates epithelialmesenchymal transition in hepatocellular carcinoma. Biochem Biophys Res Commun. 2015:467(3):589-94.

13. Altobelli E, Latella G, Morroni M, Licini C, Tossetta G, Mazzucchelli R, et al. Low HtrA1 expression in patients with long-standing ulcerative colitis and colorectal cancer. Oncol Rep. 2017;38(1):418-26.

14. Esposito V, Campioni M, De Luca A, Spugnini EP, Baldi F, Cassandro R, et al. Analysis of HtrA1 serine protease expression in human lung cancer. Anticancer Res. 2006;26(5A):3455-9.

15. Baldi A, Mottolese M, Vincenzi B, Campioni M, Mellone P, Di Marino M, et al. The serine protease HtrA1 is a novel prognostic factor for human mesothelioma. Pharmacogenomics. 2008;9(8):1069-77.

16. Weigelt B, Peterse JL. Van 't veer $L$. Breast cancer metastasis: markers and models. NatRevCancer. 2005;5(8):591-602.

17. Lorenzi T, Lorenzi M, Altobelli E, Marzioni D, Mensà E, Quaranta A, et al. HtrA1 in human urothelial bladder cancer: a secreted protein and a potential novel biomarker. Int J Cancer. 2013;133(11):2650-61.

18. Schmidt N, Irle I, Ripkens K, Lux V, Nelles J, Johannes C, et al. Epigenetic silencing of serine protease HTRA1 drives polyploidy. BMC Cancer. 2016;6:399.

19. Altobelli E, Marzioni D, Lattanzi A, Angeletti PM. HtrA1: its future potential as a novel biomarker for cancer. Oncol Rep. 2015;34(2):555-66.

20. Moher D, Liberati A, Tetzlaff, Altman DG, PRISMA Group. Preferred reporting items for systematic reviews and meta-analyses: the PRISMA statement. PLoS Med. 2009;6(6):e1000097.

21. Davey J, Turner RM, Clarke MJ, Higgins JP. Characteristics of meta-analyses and their component studies in the Cochrane Database of Systematic Reviews: a cross-sectional, descriptive analysis. BMC Med Res Methodol. 2011;11:160.

22. Boreinstein M, Hedges LV, Higgins JPT, Rothstein HR. Introduction to metaanalysis. Chichester: John Wiley \& Sons, Ltd; 2009.

23. Lipsey M, Wilson D. Practical meta-analysis. Thousand Oaks, CA: Sage; 2001.

24. Rothstein HR, Sutton AJ, Borenstein M. Publication bias in meta-analysis: prevention, assessment and adjustment. Chichester: Wiley; 2005

25. Egger M, Davey Smith G, Schneider M, Minder C. Bias in meta-analysis detected by a simple, graphical test. Brit Med J. 1997;315(7109):629-34.

26. Duval S, Tweedie R. Trim and fill: A simple funnel-plot-based method of testing and adjusting for publication bias in meta-analysis. Biometrics. 2000;56(2):455-63.

27. Duval S. The trim and fill method. In: Rothstein HR, Sutton AJ, Borenstein M, editors. Publication bias in meta-analysis. Chichester: Wiley; 2005. p. 11-33.

28. Parmar MK, Torri $V$, Stewart L. Extracting summary statistics to perform $\mathrm{m}$ ta-analyses of the published literature for survival endpoints. Stat Med. 1998;17(24):2815-34

29. Tierney JF, Stewart LA, Ghersi D, Burdett S, Sydes MR. Practical methods for incorporating summary time-to-event data into meta-analysis. Trials. 2007:8:16.

30. Williamson PR, Smith CT, Hutton JL, Marson AG. Aggregate data metaanalysis with time-to-event outcomes. Stat Med. 2002;21(22):3337-51.

31. Önder $E$, Arıkök AT, Seçkin H, Alper M. Decrease in serine protease HtrA expression correlates with grade and recurrence in meningiomas. Adv Med Sci. 2015:60(1):139-43.

32. Franco R, Collina F, Di Bonito M, Botti G, Montanaro D, Di Maio L, et al. HtrA1 loss is related to aggressive behavior parameters in sentinel node positive breast cancer. Histol Histopathol. 2015;30(6):707-14.

33. D'Angelo V, Pecoraro G, Indolfi P, lannotta A, Donofrio V, Errico ME, et al. Expression and localization of serine protease Htral in neuroblastoma: correlation with cellular differentiation grade. J Neuro-Oncol. 2014; $117(2): 287-94$
34. Zhao Z, Li H, Wang C, Xu W, Sun J, Zhao W. Serine protease HtrA1 as an inhibitor on proliferation invasion and migration of gastric cancer. Med Oncol. 2015;32(4):112.

35. Yu Y, Shao W, Hu Y, Zhang J, Song H, Zhu ZH. HtrA1 expression associated with the occurrence and development of esophageal cancer. World J Surg Oncol. 2012;10:179.

36. Xia J, Wang F, Wang L, Fan Q. Elevate serine protease HtrA1 inhibits cell proliferation, reduces invasion, and induces apoptosis in esophageal squamous cell carcinoma by blocking the nuclear factor-kB signaling pathway. Tumour Biol. 2013;34(1):317-28.

37. Zhu F, Jin L, Luo TP, Luo GH, Tan Y, Qin XH. Serine protease HtrA expression in human hepatocellular carcinoma. Hepatobiliary Pancreat Dis Int. 2010;9(5):508-12

38. Catalano V, Mellone P, d'Avino A, Shridhar V, Staccioli MP, Graziano F, et al. HtrA1, a potential predictor of response to cisplatin-based combination chemotherapy in gastric cancer. Histopathology. 2011;58(5):669-78.

39. Narkiewicz J, Lapinska-Szumczyk S, Zurawa-Janicka D, Skorko-Glonek J, Emerich J, Lipinska B. Expression of human HtrA1, HtrA2, HtrA3 and TGFbeta1 genes in primary endometrial cancer. Oncol Rep. 2009;21(6):1529-37.

40. Bowden MA, Di Nezza-Cossens LA, Jobling T, Salamonsen LA, Nie G. Serine proteases HTRA1 and HTRA3 are down-regulated with increasing grades of human endometrial cancer. Gynecol Oncol. 2006;103(1):253-60.

41. Narkiewicz J, Klasa-Mazurkiewicz D, Zurawa-Janicka D, Skorko-Glonek J, Emerich J, Lipinska B. Changes in mRNA and protein levels of human HtrA1, HtrA2 and HtrA3 in ovarian cancer. Clin Biochem. 2008;41(7-8):561-9.

42. Chien J, Aletti G, Baldi A, Catalano V, Muretto P, Keeney GL, et al. Serine protease HtrA1 modulates chemotherapy-induced cytotoxicity. J Clin Invest. 2006:116(7):1994-2004.

\section{Submit your next manuscript to BioMed Central and we will help you at every step:}

- We accept pre-submission inquiries

- Our selector tool helps you to find the most relevant journal

- We provide round the clock customer support

- Convenient online submission

- Thorough peer review

- Inclusion in PubMed and all major indexing services

- Maximum visibility for your research

Submit your manuscript at www.biomedcentral.com/submit

) Biomed Central 